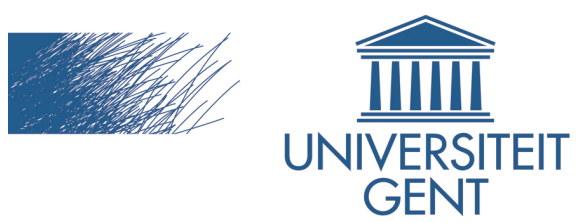

biblio.ugent.be

The UGent Institutional Repository is the electronic archiving and dissemination platform for all UGent research publications. Ghent University has implemented a mandate stipulating that all academic publications of UGent researchers should be deposited and archived in this repository. Except for items where current copyright restrictions apply, these papers are available in Open Access.

This item is the archived peer-reviewed author-version of: ID 7192105

Title Losing touch with the common tongues - the story of law French

Authors Caroline Laske

In: Journal, Volume (Issue), pages, year. International Journal of Legal Discourse 2016; 1(1): 169-192

Optional: link to the article

To refer to or to cite this work, please use the citation to the published version:

Authors (year). Title. journal Volume(Issue) page-page. Doi DOI 10.1515/ijld-2016-0002 


\title{
Caroline Laske*
}

\section{Losing touch with the common tongues - the story of law French}

DOI 10.1515/ijld-2016-0002

\begin{abstract}
This paper addresses the question of how, historically, the language of the English common law has become separated from the understanding by the ordinary man and woman. The use of an archaic language - law French - for over half a millennium has meant that legal matters had to be left in the hands of a small specifically trained elite. Law French is a language, originally based on Old Norman, Old French and Anglo-Norman. Its evolution is a complex one: its roots in Latin, it was in constant contact with the various dialects of both continental and insular French as well as the upcoming Middle English, all of which had a major impact on the medieval linguistic and cultural landscape of England. The present paper tells the story of that language, which although long gone, is still present in today's common law English. Now, as then, it contributes little to enhancing the understanding by the ordinary man and woman.
\end{abstract}

Keywords: French language in England, legal language, medieval common law

\section{Introduction}

The law and its practices have, due to historical traditions, its normative nature, prescriptive and performative functions and the basic premise that the letter of the law is supreme, developed some rather grand institutions and practices, including its use of language, as well as the actual language used. Add to this the ever-increasing legal complexities of our societies and we end up with dense legalese that has lost touch with our common tongues and which, despite the plain-English movement, is still fairly dominant. The language of the law has been 'criticized as arcane and archaic, complex and convoluted, pompous and ponderous. It has been an object of perplexity, scorn and derision' (Tiersma 1999: 241). The consequent lack of 'fairness' of its use is particularly acute in relation to, for example, consumer contracts, which govern a situation that lacks from the outset a fair distribution of bargaining power, worsened by the use of language incomprehensible to the ordinary person.

*Corresponding author: Caroline Laske, University of Ghent, Ghent, Belgium, E-mail: caroline.laske@ugent.be 
Mellinkoff (1963) identifies nine main features that characterises the language of the English common law as a specialised tongue and that, through its use, distinguishes lawyers from non-lawyers. ${ }^{1}$ Of these, in particular the first four characteristics are rooted historically, at least in parts, in the terminological vacuum that courts had to grapple with in the development of legal concepts. Certain terms/expressions have undergone a process of abstraction to a point that they can no longer be recognised as anything familiar by a non-specialist. So both lawyer and non-lawyer may use the same terms but still speak different languages.

In the history of the common law language, there was a period that shows in particular stark terms how a legal language became separated from the common tongue and the common man speaking it. The use of an archaic language - law French - from approximately the thirteenth century until 1731, continued to be practiced, hence actively excluding all those who are not familiar with it and who are thus forced to leave legal matters in the hands of a small specifically trained elite. Law French is a language, originally based on Old Norman, Old French and Anglo-Norman. The present paper tells the story of that language, described by Blackstone as a 'barbarous dialect' (Blackstone 1765: 317) and which, although long gone, is still present in today's common law English. Now, as then, it contributes little to enhancing the understanding by the ordinary man and woman.

In a first section, an overview will describe the impact French had on the medieval linguistic and cultural landscape of England, followed by a chapter on law French. A third section examines the process of increasing technicality in the language of the law, by looking at, what I have called, etymolawgy, which combines the study of the history of a term with the parallel development of the corresponding legal concept. The following two sections ask the question of whether the French of England was just a degenerate idiom or a contact variety in its own right and to what extent its continued use was serving the purpose of upholding the privileges of the upper classes by protecting their trade secrets in a foreign language. The paper finally deals with how the door was irreversibly closed on the use of law French in the eighteenth century.

\footnotetext{
1 (1) Frequent use of common words with uncommon meanings; (2) frequent use of Old English and Middle English words once in common use, but now rare; (3) frequent use of Latin words and phrases; (4) use of Old French and Anglo-Norman words which have not been taken into the general vocabulary; (5) use of terms of art; (6) use of argot; (7) frequent use of formal words; (8) deliberate use of words and expressions with flexible meanings; (9) attempts at extreme precision of expression. Mellinkoff 1963: 10-23.
} 


\section{French in Medieval England}

With the advent of Norman rule over an empire that included England from 1066, consolidated by centuries of Plantagenet rule, vast estate holdings in France and feudal alliances to the French crown, the door in England was opened to the French and their language and diverse dialects. But the exact impact of the French language and culture on the English medieval linguistic and cultural landscape is still subject to considerable debate. A lot of the thinking, at least until the middle of the twentieth century, about the linguistic situation in medieval England was skewed by the fact that linguists and historians alike have relied for decades on writings that appear to have misinterpreted or ignored historical sources, common linguistic experience and actual AngloNorman-French material. ${ }^{2}$ The view that French had first been brought over by the conquering Normans, imposed on the English, then used as a vernacular in a bilingual setting and ultimately adopted as an official language in the second half of the thirteenth century, was held by a number of writers ${ }^{3}$ on AngloNorman-French. It has, in meantime, been questioned by academics, ${ }^{4}$ based on more recent empirical research using modern linguistic methodologies. The impact and influence of French on the linguistic landscape of medieval England is much more subtle than has been propagated hitherto.

Long before the Norman conquest, the Anglo-Saxons (like the northern Teutons) had already used the vernacular to set down their laws in writing, unlike the Western Teutons of the Continent who used Latin (Brunner 1907: 8). Old English had been more mature than the Norman-French of William I's time, which was still developing from its Latin origins. And according to Woodbine, this is the reason why the Norman kings did not use Norman-French in their documents, though (besides mainly Latin) they did use English (Woodbine 1943: $404 \mathrm{fn}$. 3). In other words, English was not a lingua rustica incapable of literary culture and inadequate for official use. There can be no doubt that the invading Normans brought with them their Norman language and dialects, yet to what extent it became a widely spoken language imposed in England, let alone a vernacular, is far less clear.

First of all, the English were no strangers to the Norman language. There had been numerous contacts between the two cultures in the past. Aethelred, King of the English from 978 to 1013 and again from 1014 to 1016, married Emma

2 Wilson (1943). Rothwell made this point in several articles, especially Rothwell (1975, 1998). 3 for example: Lambley (1920); Vising (1923); Pope (1934); Orr (1948); Legge (1963); Suggett (1968).

4 for example: Woodbine (1943); Rothwell (1975, 1991, 1993a, 1998, 2001). 
of Normandy (985-1052) with the intention to pacify Normandy and unite against the invading Vikings who frequently used Normandy as their base to raid England. Aethelred, Emma and their children took refuge in Normandy during the two years that King Sweyn Forkbeard of Denmark had conquered England. When Cnut of Denmark became King of England in 1016, Aethelred's son Edward (later Edward the Confessor), who subsequently ruled England between 1042 and 1066, went into exile for two decades probably mainly in Normandy. Edward brought back a number of Norman customs, such as the sealing of documents and the seal-keeper and document secretary was described with the Norman-French term of cancheler (Mellinkoff 1963: 60). In 1051, William, later the Conqueror, had visited his childless cousin King Edward in England and the visit was returned. So, the Normans and the English were, at least on the level of their ruling class, no strangers to each other.

Secondly, the long held view that the conquerors tried to oust the English language when they landed on the southern shores, is a misinterpretation of the historical evidence. William saw himself as the rightful successor to the English throne, not as a conqueror. He tried (unsuccessfully) to learn English and was acclaimed King in French by the Normans and in English by the local population (Shelly 1921: 75, 77, 81) at his coronation in 1066. He vowed to the French and English of London to uphold the law as it had been under Edward the Confessor. ${ }^{5}$ He was, in other words, not set on dismantling the structures of English society, but rather to operate through them if appropriate. ${ }^{6}$ This also holds true for the tale that the use of French in the law was attributed directly to the Norman conquest and seen as a hallmark of Norman tyranny. ${ }^{7}$ This line of thinking goes back to some anonymous historical writings that have in meantime been revealed as a fourteenth century forgery (Woodbine 1943: 403). But its narrative continued to live in the writings of prominent authors such as Fortescue (1741) or Selden (1683). As there was no-one at Pevensey with a tape recorder in 1066 to greet the disembarking invaders, the nature of the speech they used must remain a matter of conjecture, but it is most unlikely that it could be adequately described in terms of any all-embracing formula such as 'Norman dialect' (Rothwell 1998: 150). In fact, the irretrievable loss of any substantial evidence of the spoken language output at the time of the invasion

5 "Will'm kyng gret [...] and ealle tha burhwaru binnan Londone Frencisce and Englisce freondlice. and ic kyde eaow that ic wylle that get beon eallra thaera laga weodthe the gyt waeran on Eadwerdes daege kynges [...]" Charter of William I to the City of London, in Stubbs (1913: 82-83). 6 An interesting exception to this is the imposition of political feudalism by the invading Normans and with it the import of Norman-French feudal vocabulary.

7 The so-called 'Norman yoke'. 
means we know very little about the overall English linguistic landscape of the eleventh century.

Thirdly, the premise that, following the Norman invasion, French became the vernacular in England in a bilingual set-up is a misinterpretation of the sources. If the term 'vernacular' is used in its Oxford English Dictionary (OED) definition of a language - that it is naturally spoken by the people of a particular country, rather than one acquired for commercial, social or educative purposes - there appears to be no evidence that Norman-French became the spoken language of the people in England in general as a result of the Norman invasion (Woodbine 1943: 433; Rothwell 1975: 449, 453). Similarly, there can be no question of bilingualism in the OED sense of the habitual use of two languages colloquially. The English outnumbered the incoming conquering forces. Yet, Orr speaks of a 'state of almost complete bilingualism' (Orr 1948: 5), and Legge states that 'most people, down to the very poorest, were bilingual' (Legge 1963: 4). In view of the lack of evidence of the spoken language output, as mentioned above, these writers can only have relied on written sources. But, considering the widespread illiteracy of eleventh century England, one cannot infer complete bilingualism from the existence of some Anglo-Norman-French texts, to which the great majority of the population would not have had access. Suggett, unwittingly contradicts herself by calling the Anglo-Norman 'a true vernacular whose roots had penetrated deeply into all classes of English society who could read and write' (Suggett 1968: 235). As we have seen from the OED definition, vernacular refers to spoken, not written language, and if she refers to the classes who could read and write she actually excludes the major bulk of the population. So, neither at the time of the Norman conquest, nor for the century that followed, can there be any question of French as a vernacular tongue outside the Norman elite, neither in the true sense of the word, nor in quantitative terms.

Nevertheless, it can be said that medieval England was bilingual or trilingual (adding Latin) to the extent that these languages were in use, but the distribution of that use was by no means uniform (Crespo 2000: 24, table 1). Within a century, and as a result of intermarriage, it was no longer possible to distinguish who was of Norman and who of English birth. ${ }^{8}$ The language the Normans had brought with them blended into the English linguistics landscape and was evolving fast along its own insular path. During the twelfth century, the French of the Parisian basin was becoming a more accepted standard for written

8 "Set iam cohabitantibus Anglicis et Normannis et alterutrum uxores ducentibus vel nubentibus, sic permixte sunt nationes ut vix decerni possit hodie, de liberis loquor, quis Anglicus quis Normannus sit genere." written in 1179 by Richard FitzNeale Dialogus de Scaccario, cited by Rothwell (1975) at p. 449. 
texts in Northern France, yet the different local languages with their diverse dialectical features continued to co-exist. In a parallel movement, the French of England, despite its specific insular features, became a recognised standard intelligible beyond dialectical restrictions, which was a major advantage over English (Rothwell 1975: 456).

Fourthly, the invading army of 1066 was by no means a homogeneous Norman group. William had contracted many Bretons, contingents from Picardy and further up the French coast, and included those provided to him by the Count of Flanders. In addition, the social aspect of dialectical fragmentation makes it unlikely that a common speech was even shared by the Norman section of the army.

During the thirteenth century, on both sides of the Channel, French began to develop into a language of culture, education, science, diplomacy and administration (including the law). In other words, French was used as a vehicle for ideas, a position that hitherto had been occupied only by Latin (Rothwell 1975: 464). The advantage over Latin was that the creation of new vocabulary came more easily to a living language than within the rigid constraints of an archaic one. And the advantage over English was that French could be understood more widely, while English was not be comprehended beyond its shores. ${ }^{9}$ In other words, it is less a question of French being turned into an official language during the thirteenth century and much more that the upward surge of French, as the main non-classical currency for creativity in the cultural and administrative spheres, offered the possibilities to handle and transmit new ideas and concepts. Woodbine argues that the increasingly generalised use of written French in medieval England was not a result of the Norman conquest (Norman-French) but due to the French literary revival (Central-French sources) during the reign of Henry II and his wife Eleonor of Aquitaine (Woodbine 1943: $404 \mathrm{fn} .3$ ), and subsequently, although this is disputed (Rothwell 1998: 151-152), to the major influx of French officials following Henry III's marriage to Eleanor of Provence in 1236, a period dubbed 'that other French invasion' (Woodbine 1943: 402). The age of French as a language of 'learning and gentility' was well under way (Mellinkoff 1963: 70). Hence, French was becoming more dominant, not in terms of demographic weight but in relation to cultural prestige.

Meanwhile, during the years following the Norman invasion, English ${ }^{10}$ was neglected as a language of learning and literature, but it continued on its path of

9 The great diversity of dialects in England meant that even with in its own borders people did not necessarily understand each other.

10 This was the period of Middle English, which was used in England between approx. 1100 and 1500, linking the Anglo-Saxon language with its Germanic influences of Beowulf to the 
being a popular tongue and was in constant contact with the other languages. It was developing in a rather disorderly fashion (Marsh 1869: 380), fragmented by dialects, with no rules on grammatical structure or spelling, an unsettled alphabet, and no language dictionaries (as opposed to glossaries) nor any grammatical manuals to impose some sort of uniformity (Mellinkoff 1963: 84). The thirteenth century saw a rise in feelings of English identity, starting with the loss of Normandy, the Barons' War (1258-1265), in part a reaction against foreign (French) influence, and later the hostilities with France that started the Hundred Years' War (1337-1453) during the reign of Edward III. The English Channel began to be conceptualised as a peripheral boundary marking a border, rather than a central conduit that could carry a traveller from one half of the realm to the other, as had been the case following the conquest and during the rule of the early Plantagenet/Angevin kings.

Language played an essential role in this quest for English identity. Its use became increasingly the common currency of communication, not just among the 'lower classes.' This rise in (linguistic) English identity found its expression in the 1362 Statute of Pleading, written (ironically!) in French and attempting to oust French in favour of English. Although it is concerned with the specific use of language in court pleadings, the text of the statute provides us with interesting information about language usage in general (my emphasis):

“[...] the Laws, Customs and Statutes of this Realm [...] for that they be pleaded, shewed and judged in the French Tongue, which is much unknown in the same Realm; so that the People which do implead, or be impleaded, in the King's Court, and in the Courts of other, have no Knowledge nor Understanding of that which is said for them or against them by their Serjeants and other Pleaders; and that reasonably the said Laws and Customs and known, and better understood in the Tongue used in the said Realm, and by so much every Man of the said Realm may be better govern himself without offending of the Law [...]"11

Three interesting facts are worth pointing out: first of all, French is described as a language 'trop desconue,' secondly pleading should be undertaken in the tongue that is generally understood (English), and thirdly this statute talks about the 'people' who come to court and 'every man' who wishes to respect

early Modern English of Shakespeare. It developed out of Old English (with major changes in the grammar, pronunciation and writing) and massively incorporated chunks of Norman-French and Latin. Its literary high point was the work of Chaucer.

11 Pleading in English Act 1362 (36 Edw. III c. 15): “[...] les leyes custumes \& estatutz du dit realme [...] sont pledez monstrez \& juggez en la lange Franceis, qest trop desconue en dit realme; issint q les gentz q pledent ou sont empledez en les Courtz le Roi \& les Courtz dautres, nont entendement ne conissance de ce qest dit p' eulx ne contre eulx p lour Sergeantz \& auts pledours; et q resonablement les dites leyes \& custumes sront le plus tost apris \& conuz \& mieultz entenduz en la lange usee en dit realme, et $\mathrm{p}$ tant chescun du dit realme se p'roit mieultz govner sanz faire offense a la leye [...]” 
the law and defend his belongings. In other words, although we are dealing with the restricted situation of a court of law, the statute describes the general linguistic landscape of every man and in which English was considered as the tongue generally used and French as the one too little known. The statute is notorious for having had little impact on that account. Law reporting continued in French, though admittedly this is no proof for what language was spoken in court. The fact that the statute was not followed by lawyers, shows more likely that the legislator had underestimated the influence of the bar, ${ }^{12}$ rather than questions the linguistic landscape as it had been painted in the statute.

While French was affirmed as the language of the law, its overall and more general use was declining, restricted to the noble, wealthy and powerful (Mellinkoff 1963: 95-96). Yet its standing as the language of learning meant that English speakers enhanced their language with 'high-class' foreign usage (Jespersen 1935/1955: 47) or simply because, at times, they found the French vocabulary more effective. Surveys show that the period of the most extensive penetration of French words into English is 1251-1400 (Mellinkoff 1963: 97). Crystal (2004: 155) estimates that of the 27,000 words which got absorbed into the English language during that time, 22\% (approx. 5,940 words) were words of French origin (2,500 French words alone in the period 1375-1400). Baugh claims that during the Middle English period, about 10,000 French (including AngloFrench and continental French) words entered into the English language, of which some 7,500 are still in use today (Baugh 1935: 220). The way these words were absorbed happened in different ways: a French word may simply replace an Anglo-Saxon one or juxtaposed to it, expressing a new meaning, or even name something new or unknown. The generally held view is that French words were borrowed in the context of cultural life, of the nobility, of social elites, and of political and religious powers, while the basic vocabulary of the English language relating to semantics of daily life, popular culture and emotions remained Anglo-Saxon (Lusignan 2009: 24, challenged by Rothwell 1996: 41-51).

The socio-linguistic take on this would be that language typically evolves when individuals diversify their social relations, and hence become mediators between their own social circle and the new one(s) they operate in. The French of the English upper classes trickled further into English society by the inevitable interaction between the lords and their servants, bailiffs and manorial stewards and the increasingly professionalised administrative classes in institutions relating to justice, administration and representation. Lawyers, royal officers and

12 The reforms undertaken during the reign of Edward I (1272-1307) substantially settled the jurisdiction of the common law courts and thus professionalised the practice of the law. This resulted in a significant rise in the power of the bar and the legal profession in general. 
parliamentary representatives further propagated the absorption of French words into the English language in their interaction with their own circles (Lusignan 2009: 25, based on Milroy's model, Milroy 1992). In addition, but on a different level, literary grandees of the fourteenth century like Chaucer, Wycliff and Langland continued to enrich Middle English, already permeated by French vocabulary, with cultural importations from a variety of sources in several languages.

In the context of medieval text production, which is never truly monoglot, the linguistic landscape of multilingual England is particularly diverse. Boundaries between languages were porous and language contact phenomena such as, for example, code-switching ${ }^{13}$ and calque ${ }^{14}$ meant there was continuous interplay and lexical borrowings, in particular, between continental (Parisian) French, insular French and Middle English on English soil. Rothwell provides us with examples, which clearly shows that, at times, the French of England went its own semantic way irrespective of developments in continental French (Rothwell 1993b: 584-585; Rothwell 1998: 156). So Anglo-French and the absorption of French words into Middle English were the results of language contacts on English soil. In other words, Anglo-French was a contact variety of French in its own right and should be considered as a part of the medieval French dialect continuum (Trotter 2003: 427-428). According to Ingham, this was only possible if (later) 'Anglo-Norman was maintained by bilingual speakers into the fourteenth century, rather than being taught as an instructed second language, and that contact via bilingualism was the factor that brought about departures in Anglo-Norman from Continental French' (Ingham 2010: 9). To that extent the French in England was both influencing English as well as being influenced by it.

\section{Law French}

The linguistic landscape of medieval England was inhabited by three languages Latin, English and French - though not in equal shares - but in continuous and subtle intermingling, in particular of the French and English languages and cultures. The role each language played, changed and evolved both in time and in terms of geographical and geo-political distribution. It is precisely that intermingling/interlocking of tongues that can be so well observed in the medieval language of the English common law.

13 Code switching in linguistic terms is the practice of alternating in conversation between two or more languages or language varieties, using them in a way consistent with the phonology and syntax of each language.

14 Calque, also called loan translation, occurs when a phrase or word is borrowed from another language by literal translation and introduced in the target language as a new lexeme. 
As mentioned earlier, originally the use of French in the law was attributed directly to the Norman conquest and seen as a hallmark of Norman tyranny. However, this contradicts William I's promise to uphold the law as it had been under Edward the Confessor, as well as the general message he wanted to put across, namely that he was the rightful successor to the crown. It is interesting to note that the political feudalism that was brought over and imposed by the Normans came with the vocabulary that applied to it. These Norman-French terms of feudal import described the relationships and functioning of feudalism, unknown in England as such before the Norman invasion. However, in general, the Normans did not use French but Latin in their legal documents. It is, therefore, likely that they continued to do so on arrival in England. ${ }^{15}$ It is also important to note that the French language of Westminster and of the King's Court had evolved, from the tongue brought over by the conquering Normans two centuries before (see above), into a dialect with strong Picard and Angevin influences (Baker 1998: 17) and as a part of the medieval dialect continuum.

The textual evidence of the earliest surviving plea rolls of the English royal courts from the 1190s shows the use of Latin, though it is unlikely that it was also spoken in court (Brand 2010: 95; Pollock and Maitland 1898: 66). Writs and charters were written in Latin, but some were in English and a few in both languages (Woodbine 1943: 405). ${ }^{16}$ Fact is that in the second half of the thirteenth century, ${ }^{17}$ French became the language used for official documents, legal tracts, treatises and statutes - 'something happens to make Englishmen write about law in French and frame statutes in that language' (Woodbine 1943: 402).

From the textual evidence we can see that from the time of Edward I (12721307), French was the language used for the formal initiation and subsequent argument conducted in the courts (Woodbine 1943: 434; Brand 2000: 75). ${ }^{18}$ Though it may well be that French was introduced in the royal (common law) courts when these were established under the French-speaking (though he understood English) Henry II (1154-1189) (Brand 2010: 95). This would, however, have been a different tongue to the Norman-French William I brought over from Normandy. Under Henry's great grandson, Edward I, major constitutional, administrative and judicial reforms were put in place. The judiciary was professionalised and began to form

15 Two centuries later the Record's Commission's Statutes of the Realm shows the first twelve entries between 1236 and 1267 (incl. Statute of Merton 1236, Statute of Marlborough 1267) to be still all in Latin.

16 Footnote 3 for textual sources used and statistical analysis of languages used.

17 There is textual evidence that French was used in legal texts before the second half of the thirteenth century. Rothwell (1975: 457, 1993: 262).

18 French was not only used in pleadings at the royal court's but also in some county and city courts, see Brand (2000: 75). 
an organised legal body. This improved standards of professional conduct, but it also meant that the law was becoming a 'closed profession' (Plucknett 1956: 217-219). This was emphasised by the use of a language not generally comprehensible by the ordinary man and further separated lawyers from laymen.

During that same period, court case reporting, which, unlike later law reporting, also included personal comments, notes, criticisms and speculations, were first compiled in the Year Books. ${ }^{19}$ These were written in French, which does not necessarily mean it was also the language spoken in court pleadings (Plucknett 1956: 268; Pollock and Maitland 1898: 84-85; Woodbine 1943: 426-428, 433-435). The language of monopoly for statutes had hitherto always been Latin. In the second half of the thirteenth century, French began to be used, and it dominated by the fourteenth century. ${ }^{20}$ Practical pleading compilations also appeared in French, e. g. Brevia Pleidez (1260), Fat Asaver, La Court de Baron (c.1265), Le Ple de la Coroune, as well as law treatises for practising lawyers, e. g. Britton (1290) Glanvil had been translated into French (Plucknett 1958: 79-82) - and fifteenth century law books, such as Littleton's Tenures (1481/82) and the Statham's Abridgment of the Law (1490s), sixteenth century Fitzherbert La Graunde Abridgement (1541) collection of Year Books cases and attempt to provide a summary of English law, Broke Le Graunde Abridgement (posth. 1578) etc. French also became the language of English legal instruction (Brand 2000: 72) and for moots in the Inner Temple (Baker 1998: 20).

The 1362 Statute of Pleading is notorious for having had little impact on the use of English in court proceedings. A century later, Fortescue suggested that the courts took no notice of the provisions, because lawyers could not do without the 'terms which pleaders do more properly express in French than in English' (Fortescue 1942: 114; Holdsworth 1927: 478). Law reporting continued in French until the seventeenth century, though this is no proof for what language was actually spoken in court.

19 These runs approx. from 1260 to 1535 , unlikely to have been written by officially appointed reporters, handed down from private collections (unlike the French 'Olim'), see Maitland (1903: xiii); Plucknett (1956: 268-273).

20 Record's Commission's Statutes of the Realm show the following entries: first twelve entries between 1236 and 1267 (incl. Statute of Merton 1236, Statute of Marlborough 1267) are all in Latin; 1275: first Statute of Westminster in French; then three in Latin, two in French, two in Latin, three in French etc.,; 1285: Statute of Westminster is both in Latin and French; 1290: eleven entries in Latin and nine in French; Statute of Mortmain and all statutes of 1291-95 are in Latin; 1297: confirmation of Great Charter in both Latin and French; until 1307 (end of reign of Edw. I) nine statutes in Latin, seven in French; 1307-27: one in both Latin and French, six in Latin, fifteen in French; during reign of Edw. III of 55 entries 52 were in French. Data from G. Woodbine (1943) The Language of English Law, 18 Speculum 395, p. 401, ft.4. 
The intriguing question of why the use of French in the law rose and persisted, has preoccupied generations of writers and been the subject of much speculation. Some (Woodbine 1943: 402) have connected the phenomenon to the contemporary event of a major influx of French courtiers following Henry III's marriage to Eleanor of Provence in 1236. But it is likely that the Barons' War and the not-very-Francophile Edward I made an end to this development and yet French persisted.

In all probability, French was the most convenient and practical language to use. Latin, though the language of the learned, was rigid and archaic and lend itself not necessarily well to be adapted to the new situations of an evolving society and legal system. English, on the other hand, was still fairly untried in the thirteenth century, especially in relation to the demands of the writ systems that required strict adherence to the prescribed form of the writ, any lapse from which would bring about a failure of an action. With Latin as the source language, it was easier to transpose more precisely into the closely related French as the target language than into the very different English. In other words, French was the most operative language at that time and it therefore played a pivotal role in that era when the foundations of the English common law systems were being laid.

It has been said that 'lawyer and law French are coincident; one will not stand without the other' and that 'really the Law is scarce expressible properly in English' (North 1824: 11, 13). It was like a dual building site of two edifices that propped each other up: the law and the development of its concepts, on the one hand, and the language and the evolution of its technical, specialised vocabulary, on the other. Brand argued that the existence of a specialist legal vocabulary in Insular French can be traced back to before the emergence of the legal profession and, while it does not as such owe its existence to that profession, its future evolutions certainly happened at the hands of the English lawyers (Brand 2010: 100). The 'English bar and bench [...] used Anglo-French to create an entirely new legal vocabulary, the basis indeed of a new jurisprudence, by giving special meanings to ordinary words' (Baker 1990: 4). Maitland described it as the 'elaboration of rough native material into a highly technical, but at the same time durable, scheme of terms and concepts' (Maitland 1903: xviii). The continuous and highly specialised use of French within the closed ranks of lawyers resulted not only in the formation of the specialised law French but also in a separation of this professional jargon from the French that was massively imported into English. The central residue was the technical part of law French, while the everyday terminology was gradually taken over by English. What we are left with is a 'lingering professional dialect, more often written than spoken' (Baker 1990: 3). But it evolved in sophistication and 
abstractness in parallel with the development of law and legal concepts it was used to describe and was like a kind of shorthand. It became 'highly technical because English lawyers had been able to make a vocabulary, to define their concepts, to think sharply as the man of science thinks' (Maitland 1903: xxxvi). Once the upswing of the legal profession and the law in general went hand in hand with the blossoming of law French, the two were intrinsically linked, and survived even during a period when in general terms French gave way to English. Law French was like a hyphen that kept alive the general framework of an earlier vocabulary and syntax until a time when English had become a full and flexible language and had appropriated all the necessary French elements, expressions and vocabulary (Stoljar 1954: 224).

Law French was not a foreign tongue, but started as the general French of Westminster Hall with all the inconsistencies in its spelling (Maitland 1903: xxxiii, xliii). Yet, as described above, its use was more operative than the less learned English. Later, when Coke translated Littleton's Tenure from law French into English, he carried over a great many terms without much change, which in itself is an indication of the extent to which technical law French easily became a part of the English law language, e. g. the French fee simple became fee simple (Coke 1703: f.1a), the French fee taile became fee tail (Coke 1703: f.18b), the French heires became heirs (Coke 1703: f.1a).

Pollock and Maitland have drawn up a (non-exhaustive) list of French words basic to the law vocabulary (1898: 81$)$ :

$\begin{array}{llll}\text { action } & \text { damage } & \text { judges } & \text { pledge } \\ \text { agreement } & \text { debt } & \text { judgment } & \text { police } \\ \text { appeal } & \text { declaration } & \text { jurors } & \text { possession } \\ \text { arrests } & \text { defendant } & \text { justice } & \text { prisons } \\ \text { arson } & \text { demand } & \text { justices } & \text { property } \\ \text { assault } & \text { descent } & \text { larceny } & \text { purchase } \\ \text { attorneys } & \text { devise } & \text { lien } & \text { reprieve } \\ \text { battery } & \text { easement } & \text { marriage } & \text { robbery } \\ \text { Bill } & \text { evidence } & \text { misdemeano(u)r } & \text { sentence } \\ \text { Claim } & \text { execution } & \text { money } & \text { servant } \\ \text { condition } & \text { felony } & \text { note } & \text { slander } \\ \text { constables } & \text { gaols } & \text { obligation } & \text { Suit } \\ \text { contract } & \text { grant } & \text { pardon } & \text { tort } \\ \text { counsel } & \text { guarantee } & \text { parties } & \text { treason } \\ \text { count } & \text { guardian } & \text { partner } & \text { trespass } \\ \text { court } & \text { heir } & \text { payment } & \text { verdict } \\ \text { covenant } & \text { indictment } & \text { plaintiff } & \\ \text { crime } & \text { infant } & \text { pleadings } & \end{array}$


More than half of these came into written English with a legal meaning by the middle of the fourteenth century. Today, we would recognise this list to be no longer exclusive to the field of law, nor would we think of most words as particularly foreign, they have become common currency in contemporary English. Yet, a great many terms have very specifically technical legal meanings. If we take the words 'trespass' and 'covenant', for example, it is understood by the ordinary man as a wrongdoing or transgression in the case of the former and as an agreement in the broad sense of the latter. And yet, it has very precise meanings for the common law lawyer who applies these terms to very specific circumstances. So both lawyer and non-lawyer use the same terms but still speak different languages.

Moreover, a number of law French terms and phrases have survived in today's common law English that are distinct from both the English words of French origin and modern French (Mellinkoff 1963: 16):

alien, in the sense of to transfer

cestui que trust

chose in action

de son tort

estoppel

estoppel in pais

esquire

fee simple and feetail, which like attorney general retain the French word order laches

metes and bounds

oyez

pur autre vie

quash

roll, as in judgment roll

save, in the sense of except

speciality, in the sense of sealed contract

voire dire

In its beginnings, the French used in the law was not as such a technical language. But with time and the general decline of French in England, law French became a highly specialised use of that language within the closed confines of the legal profession and abstract from everyday usages. The language contact was such that, on the one hand, the French used in the law took an independent path from the French that became mass absorbed into the English language. On the other hand, lawyers speaking native English and acquiring French, constituted the link that allowed for great quantities of 
French words with legal connotations to penetrate the English language (Mellinkoff 1963: 109).

\section{Etymolawgy}

The process of increasing technicality in the language can be well observed by practising some etymolawgy, ${ }^{21}$ that is to combine the study of the history of a term with the parallel development of the corresponding legal concept. of particular interest are the words that show, across time, the same (or similar) form but no continuation in meaning. This sort of refinement is at the heart of separating the language of the law from the common tongues.

The term tort, for example, came into the eleventh century Old French from the Medieval Latin tortum ${ }^{22}$ meaning wrong, injustice, tortus, tortum (wrung, twisted), past participle of Latin torquere (to twist, wring). It has that sense in the Chanson de Roland (twelfth century) ${ }^{23}$ and troubadours literature. ${ }^{24}$ The law of negligence, as we know it today, goes back to the thirteenth century in the form of actions of trespass and actions on the case. Various terms were used to describe personal remedies concepts. The term tort first materialised in the $1580 \mathrm{~s}^{25}$ in the context of legal action for breach of duty. But early tort law dealt with the most serious wrongs such as bodily harm, damage to goods and trespass to land. During the nineteenth and twentieth centuries, the action was extended to cover intentional and negligent infliction of economic loss as well as some emotional, psychological reputational etc. injuries. In other words, the term tort has evolved from the Old French general meaning of injustice and wrong, which incidentally is still its modern French meaning, to cover today's very specialised type of wrong. Similarly, seisin came from the thirteenth century French saisine and meant possession in its early general use, mainly in the phrases: to have take seisin (in, of), and this long before it came to mean what it does in land law (possession as of freehold). ${ }^{26}$ Slander, originates in the AngloNorman etymology of esclaundre and the Old French esclandre. It was used to

21 This term has been coined inspired by Stoljar's neologism of phi law logy, see Stoljar (1954: 124).

22 compare tortum facere, 864, in Capitul. Caroli II.

23 Verse 1015: Paienunt tort e chrestiensuntdreit.

24 e. g. Guillaume de Cabestaing (twelfth/thirteenth century): Fis amans deugran tort perdonar (Lo jornqu'ie us).

25 see OED entry for 'tort'.

26 see OED entry for 'seisin'. 
describe both oral and written defamation and today's OED also includes both meanings. Yet the law began to make a distinction between the action of slander and that of libel from the seventeenth century (Plucknett 1956: 467).

Another interesting example is purchase. The various early etymological roots - Anglo-Norman, Old French, Middle French - identified by the OED all reflect personal effort to obtain something - effort, striving, doing, acquisition, collection, action of attempting to bring about or cause something, but also plunder, booty, spoil. In the late thirteenth century appears the notion of acquisition of property other than by inheritance. Melinkoff (1963: 108-109) takes up the story and relates how purchase was defined in the fifteenth century by Littleton as the possession one has not by descent but: ...per son fait, ou per agreement, and translated two centuries later by Coke as: ...by his deed or agreement, adding in his comment that a gift was also a purchase. This rationale is taken up by Blackstone ${ }^{27}$ by describing that one who receives a gift ... comes to the estate by his own agreement, that is, he consents to the gift. By including the notion of gift, the law French purchase has lost touch both from the ancient etymology of personal effort and from the layperson's understanding of paying something. Adding to the confusion, purchase can be found in the law interchangeably with the Old English buy. Melinkoff concludes that 'the law has adopted the buy sense of purchase in such special law terms as purchase money, purchase-money mortgage, purchase-price, and bona fide purchaser - all truer to the etymology of purchase than the land law's term of art.' (Mellinkoff 1963: 109).

Similar etymolawgy inquiries can be made with a great many other terms. The term defendant came into English from the Old French deffendant with the general fourteenth century meaning of (self) defense (him self defendaunt). The law word in the sense we know today appeared in the fifteenth century. ${ }^{28}$ Similarly, action (general use: taking legal action $v$. specialised use: an action), indictment (more general use: an indictment $v$. specialised use: the indictment) etc.- it is always the same story of the legal language losing touch with the common tongue by continuous refinement and increased technicality to a point some English legal terms have become more technical than the earlier law French contributions (Mellinkoff 1963: 119) ${ }^{29}$

27 Blackstone 2 Commentaries.

28 OED entry for defendant, A1 and B3.

29 Mellinkoff lists examples of English legal terms that are more technical than the earlier law French contributions. 


\section{Diglossia, a 'barbarous dialect' or a contact variety in its own right?}

This paper has followed the rest of the literature by describing the linguistic situation in medieval England as bi- or multilingual rather than diglossia. In his ground-breaking article of 1959, Ferguson defines diglossia as:

... a relatively stable language situation in which, in addition to the primary dialects of the language (which may include a standard or regional standards), there is a very divergent, highly codified (often grammatically more complex) superposed variety, the vehicle of a large and respected body of written literature, either of an earlier period or in another speech community, which is learned largely by formal education and is used for most written and formal spoken purposes but is not used by any section of the community for ordinary conversation.

This was subsequently extended by Fishman (1967) to include the use of unrelated languages beyond mere dialectical variations. The linguistic situation of medieval England is somewhat different to the ones Ferguson ${ }^{30}$ had in mind when he formulated his concept, mainly because of the inherently unstable situation of the languages in question. The Middle Ages was an era when texts interchanged their languages both in terms of phraseology as well as lexis, responding to constantly changing socio-cultural and (geo-) political circumstances. Language contact models were therefore extremely complex with "deeply interwoven lexical borrowings back and forth from English to French and from French to English that makes the boundaries of our modern dictionaries of 'Middle English' and 'Anglo-Norman' themselves problematic” (Wogan-Browne 2009: 6). The 'relatively stable language situation' of Ferguson's diglossia definition does not correspond to the realities of medieval text production, at least not during the period when both Middle English and the French of England were in constant mutation. From the period of early modern or Tudor English, when English had gained the upper hand and ousted French in all but a few sectors, law French showed characteristics of being a 'very divergent, superposed variety' as defined by Ferguson. If the concept of diglossia could be used it may be in relation to that period. Yet the hierarchical notion of $\mathrm{H}$ (the prestigious, codified varieties used in education) and L(ower) varieties is not appropriate. Law French was not highly codified but in a gradual process of degeneration, but its use continued because it had developed appropriate vocabulary for

30 Greece: the alternation of Katharevusa and Demotic; Switzerland: the alternation of Swiss German and German Arabic-speaking countries: the coexistence of literary and dialectal Arabic; Haiti: the later nation of Creole and French. 
expressing legal concepts. This vocabulary was in the process of being totally absorbed into the English language during the Tudor era.

It has traditionally been argued that the everyday use of French was abandoned from the mid-13th and especially fourteenth centuries in favour of English, and that French declined into a corrupt language. It was described as 'mauvais français [...] en Angleterre' (Meyer and Toulmin-Smith 1889) and degenerate to a point where it 'gradually became a dead language that [...] always had to be taught' (Pope 1934: 424). Price describes it as 'a language in advanced state of decline.' He adds that 'grammatically it was often little more than 'bad French' [...] Late Anglo-Norman is characterised by so many and such marked deviations from any other kind of French at the time as to lead one to the view that what we have before is not just another authentic speaker French but incorrect French written by people for whom it was foreign language and whose command of it was inadequate' (Price 1984: 224). The key lies in the notion of deviation from any other kind of French: as long as the French of England is being compared to Continental French, it will appear as an imperfectly learned second language on the path to serious degeneration. If the Insular French was indeed in such decline, it appears difficult to explain why this language was still being used for communication and record keeping in the law, as well as for administrative, political, financial and commercial matters (Lusignan 2004).

More recent research - and a lot more work is still required in this field has suggested the French of England as a contact variety of French in its own right (Ingham 2010a, 2010b). And it is this very language contact that has put the French of England on a different path from the Continental French, in relation of lexis or morphology, for example. Ingham shows how supposedly deviant grammatical features, such as chaotic gender-marking on articles and modifiers, or the lack of a tonic/atonic object personal pronoun distinction, or the extension of the -er ending of the first conjugation to other classes can be explained with a view to the wider historical contexts of language contact influences and a general medieval dialect continuum. In other words, we are less dealing with divergence due to imperfect second language acquisition, but rather with disparity between first language dialects.

\section{Protecting privileges}

During the sixteenth century, law French was still used at the Inns of Court and very occasionally in the law courts, the early law reports ${ }^{31}$ were also written in

31 The so-called 'old' reports first appeared during the reign of Henry VIII and ran until 1865. These were 'nomiante' reports because they were written and signed by private reporters. 
French. The legal profession hung onto this idiom that had shaped their law, legal thinking, habits and the construction of their concepts and arguments. Coke described law French as 'vocabula artis [...] so apt and significant to express the true sense of the laws, and are so woven in the laws themselves, as it is in a manner impossible to change them [...]'. He practiced what he preached in the sense that in his translation of Littleton he simply transferred much of the technical law French vocabulary straight into English. ${ }^{32}$ In his Commentary upon Littleton (1628), Coke thought law French to be 'most commonly written and read, and very rarely spoken' (Coke 1832: xxxix). In other words, he acknowledged the use of law French as very restricted. But when he published his Reports (1600-1615), he did so in French, because he contended that: 'it was not thought fit nor convenient, to publish either those or any of the statutes enacted in those days in the vulgar tongue.' He used the language to which he was accustomed and warned at the same time that publishing his reports in English would raise the risk that 'the unlearned by bare reading without right understanding might suck out errors, and trusting to their conceit, light endamage themselves, and sometimes fall into destruction. ${ }^{33}$ In other words, the reading of the law should be restricted to those who understand the tongue in which it is written. This is echoed by Bulstrode (1688) in the introduction to his reports where he describes the use of French as 'being most proper [...] and most convenient for the Professors of the law, who indeed are the only competent judges thereof. For the laws of England, do best commend themselves to them that understand them.'

This echoes the charge that has been levelled against the use of law French. Bentham famously wrote that 'a large portion of the body of the law was, by the bigotry or artifice of lawyers, locked up in an illegible character, and in a foreign tongue' (Bentham 1823: xxxv). It is an idiom known to the noble and wealthy classes and their sons, often educated in the law. Even from the time when English became more common, the wealthy, keen to maintain their privileges through land law, in particular, continued the use of law French for the reasons mentioned above, but also to 'lock up trade secrets in the safe of an unknown tongue' (Mellinkoff 1963: 101). John Warr suggests that 'the unknownness of the law, being in a strange tongue; whereas, when the law was in a known language, as before the Conquest, a man might be his own advocate. But the hiddenness of the law, together with the fallacies and doubts thereof, render us in a posture unable to extricate ourselves; but we must have recourse to the shrine of the lawyer, whose oracle is in such request, because it pretends to

32 for example: fee simple was fee simple, fee taile became fee tail, heires became heirs.

333 Co. Rep. xl. 
resolve doubts' (Warr 1810: 221-223). There is little evidence for this being a deliberate process, but it was certainly a collateral benefit for the powerful. As Mellinkoff (1963: 36) pointed out, it has been done before by the Celts who apparently perpetuated their customary law in a 'learned archaic language'. It is significant that the general movement of making things more accessible to the ordinary man during the Interregnum of 1649-1660, brought a major onslaught on the use of law French, which, by that time, had become totally incomprehensible to anyone but the initiated.

\section{Demise of law French}

Returning to the nine main features identified by Mellinkoff ${ }^{34}$ that characterise the language of the English common law as a specialised tongue, it was not merely the use of law French that made it increasingly technical, abstract and detached from the common tongue. Particularly rich borrowings had been made from other languages, including also remnants of Old English and Middle English, as well as many words with Scandinavian etymologies. ${ }^{35}$ But the bulk came from Latin directly or indirectly through French or French sources. An 'addiction' to a 'grand mixture of languages', including deposits of Celtic and Norse, Latin and French has brought the warehouse of word material to overflowing, producing a number of phenomena, such as word doubling, bilingual synonyms, multiplying words etc. (Mellinkoff 1963: 120-122) which contributed to the language of the law being wordy, opaque and unclear. Add to this the use of court hand, abbreviations and increased condensation by the printers (Mellinkoff 1963: 86-88), and it is not surprising that the reforms of the Commonwealth period also included the language of the law, which had not been accessible to the ordinary literate layman for centuries and which the revolutionaries wanted to abolish in favour of a pocket book code in plain English.

During the Interregnum, an Act of Parliament ${ }^{36}$ attempted to abolish the use of any language other than English in all law writings and proceedings. It was blanket ban and stipulated that:

34 See note 1 above.

35 The term "law" came into Old English in about the year 1000 from the Old Norse, where in turn it had been derived from Old Icelandic words.

36 An Act for turning the Books of the Law, and all Proces and Proceedings in Courts of Justice, into English; November 1650 Acts and Ordinances of the Interregnum, His Majesty's Stationery Office, London 1911 at pp. 455-456. 


\begin{abstract}
“[...] Report-Books of the Resolutions of Judges, and other Books of the Law of England, shall be Translated into the English tongue [...] all Reports-Books of the Resolutions of Judges and all other Books of the Law of England, which shall be Printed, shall be in the English tongue only [...] all Writs, Proces and Returns thereof, and all Pleadings, Rules, Orders, Indictments, Inquisitions, Certificates; and all Patents, Commissions, Records, Judgements, Statutes, Recognizances, Rolls, Entries, and Proceedings of Courts Leet, Courts Baron, and Customary Courts, and all Proceedings whatsoever in any Courts of Justice within this Commonwealth, and which concerns the Law, and Administration of Justice, shall be in the English Tongue only, and not in Latin or French, or any other Language then English [...]”
\end{abstract}

This was greeted with little enthusiasm by the legal profession, who felt deprived of their privileged position and had little patience for what they perceived as an unprofessional break with tradition. William Style (1658), who saw himself forced to make his 'reports speak English' from his law French personal notes, ${ }^{37}$ wrote in his introduction that he had obeyed authority, but that the 'part of the Common Law which is in English hath only occasioned the making of unquiet spirits contentiously knowing, and more apt to offend others, than to defend themselves.'

Prior to the Cromwell's statutory reforms, only one set of law reports ${ }^{38}$ was written in English. During the decade of the Interregnum, ten reports were published, of which only two were originally composed in English, while the others were written in French but immediately translated into English by the publishers, as required by statute. With the restoration, law reports were once again published in French and the pleading form reverted to Latin. Benloe, Jenkins and Yelverton (all in 1661), Latch (1663), Jones, Rolle and Savile (all in 1675), Palmer (1678), Siderfin (1683-84), Saunders (1686) all published their reports in French. But the clock could not really be turned back. The English language had become a more integral part of the common law. Hardes (1693) reports are in English and after 1704 all reports were in that language (Holdsworth 1924: 552-554). By that time, law French had been totally absorbed by English and its use was banned in 1731 by statute, ${ }^{39}$ an instrument that confirmed an established situation rather than introduced a radical change. Its aim was to protect:

those who are summoned and impleaded having no knowledge or understanding of what is alleged for or against them in the pleadings of their lawyers and attornies, who use a character not legible to any but persons practising the law: To remedy these great mischiefs, and to protect the loves and fortunes of the subjects [...] more effectually than heretofore, from the peril of being ensnared or brought in danger by forms and proceedings in courts of justice, in an unknown language, be it enacted [... that] all proceeding

37 “...taken by me in Law-french..."

38 The Reports of that Learned Sir Henry Hobart (1641), London.

39 Proceedings in Courts of Justice Act 1730, 4 Geo II. c. 26. 
whatsoever in any courts of justice [...] and which concern the law and administration of justice, shall be in the English tongue and language only, and not in Latin or French, or any other tongue and language whatsoever, and shall be written in such a common legible hand and character, as the acts of parliament are usually ingrossed in, and the lines and words of the same to be written at least as close as the said acts usually are, and not in any hand commonly called courts hand, and in words at length and not abbreviated [...]

The use of law French had come irreversibly to an end. With the 1731 Statute, the use of English was officially established in the law and all other languages banned. Yet two years later, it was necessary to enact further legislation ${ }^{40}$ to allow for expressions such as nisi prius, habeas corpus etc. to be used and which had become so entrenched in the legal vocabulary that it appeared impossible to anglicise them. Moreover, the legacy of law French even in today's common law English is undeniable. But the development of such a highly technical and precise legal language has also meant that a certain rigidity renders it incapable of the slightest change, with the inevitable result that 'both the law and the language will tend to lose touch with common life' (Holdsworth 1923a, 1923b: 482). Blackstone remarked very pertinently in his Commentaries of the purpose of the reforms to make the law more comprehensible for the common people: 'I know not how well it has answered, but am apt to suspect that the people are now, after many years' experience, altogether as ignorant in matters of law as before.'

The exclusive use of English for the common law from the eighteenth century coincided with more general developments in English law during that century, in particular in the fields of tort and contract, which moved the common law further away from its Anglo-Norman roots. English now played a similar role to the one of law French during the times of Edward I as the linguistic vehicle for the reforms. Starting with Blackstone in the second half of the 18th century, a number of treatise writers sought to systemise the common law or certain aspects of it, using English as their language. Law French, which had once displaced Latin, had now itself been ousted by English: sic transit gloria mundi.

\section{References}

Baker, J.H. 1990. Manual of law French, 2nd ed. Aldershot: Scolar Press.

Baker, J.H. 1998. The three languages of the common law. McGill Law Journal 43. 5-24

Baugh, A. 1935. A history of the English language. New York: Appleton-Century.

Bentham, J. 1823. A fragment on government, Or, a comment on the commentaries.

London: E. Wilson.

406 Geo. II, c. 14; 6 Geo II c. 6. 
Blackstone, W. 1765. Commentaries on the laws of England, vol. III. Oxford: Clarendon Press. Brand, P. 2000. The languages of the law in later medieval England. In D. Trotter (ed.), Multilingualism in later medieval Britain, 63-76. Cambridge: Brewer

Brand, P. 2010. The language of the English legal profession: The emergence of a distinctive legal lexicon on insular French. In R. Ingham (ed.), The Anglo-Norman language and its contexts, 94-101. York: York Medieval Press.

Brunner, H. 1907. The sources of English law. In Committee of the Association of American Law Schools. Select essays in Anglo-American legal history, vol. 2, 7-52. Boston: Little, Brown \& Co.

Bulstrode, E. 1688. Reports, 2nd ed., pt. 2 To the Reader.

Coke, E. 1703. Commentary upon Littleton, 10th ed. London: Rawlins and Roycroft.

Coke, E. 1832. Commentary upon Littleton, 19th ed. London: Clarke, Saunders \& Benning.

Crespo, B. 2000. Historical background of multilingualism and its impact on English.

In D. Trotter (ed.), Multilingualism in later medieval Britain, 23-36. Cambridge: Brewer.

Crystal, D. 2004. The stories of English. Woodstock: Overlook Press.

Ferguson, C. 1959. Diglossia. Word 15. 325-340.

Fishman, J. 1967. Bilingualism with and without diglossia; diglossia with and without bilingualism. Journal of Social Issues 23(2). 29-38.

Fortescue, J. 1741. De Laudibus Legum Angliae, 2nd ed. cc. 47, 48.

Fortescue, J. 1942 (ed. S. Chrimes). De Laudibus Legum Angliae, Cambridge: Cambridge University Press.

Holdsworth, W.S. 1923a. A history of English Law, 3rd ed., vol. 2. London: Methuen.

Holdsworth, W.S. 1923a. A history of English law, 3rd ed., vol. 3. London: Methuen.

Holdsworth, W.S. 1924. A history of English law, vol. 6. London: Methuen.

Holdsworth, W.S. 1927. A history of English law, 4th ed., vol. 2. London: Methuen.

Ingham, R. 2010a. Later Anglo-Norman as a contact variety of French? In R. Ingham (ed.), The Anglo-Norman language and its contexts. York: York Medieval Press.

Ingham, R. 2010b. The transmission of later Anglo-Norman: Some syntactic evidence. In R. Ingham (ed.), The Anglo-Norman language and its contexts, 164-182. York: York Medieval Press.

Jespersen, 0. 1955 reprint/1935. Growth and structure of the English language. Garden City: Doubleday.

Lambley, K. 1920. The teaching and cultivation of the French language in England. Manchester: The University Press.

Legge, M. 1963. Anglo-Norman literature and its background. Oxford: Clarendon Press.

Lusignan, S. 2004. La langue des rois au moyen âge: le français en France et en Angleterre. Paris: PUF.

Lusignan, S. 2009. French language in contact with English: Social context and linguistic change. In J. Wogan-Browne, C. Colette, M. Kowaleski, L. Mooney, A. Putter, D. Trotter, (eds.), Language and culture in Medieval Britain, 19-30. York: York Medieval Press.

Maitland, F.W. 1903. Of the Anglo-French Language in the Early Year Books In Introduction to Year Books of Edward II, 17 Selden Society.

Marsh, G. 1869. The origin and history of the English. London: Sampson Low \& Co. language. Mellinkoff, D. 1963. The language of the law. Boston: Little, Brown \& Co.

Meyer, P. \& Toulmin-Smith, L. 1889. Les contes moralisés de Nicole Bonzon. Paris: Société des anciens textes français.

Milroy, J. 1992. Linguistic variation and change. Oxford: Blackwell. 
North, R. 1824. A discourse upon the study of the laws. London: C. Baldwyn.

Orr, J. 1948. The impact of French on English, The Taylorian Lecture. Oxford: Clarendon Press. Plucknett, T. 1956. A concise history of the common law, 5th ed. Boston: Little, Brown and Co. Plucknett, T. 1958. Early English legal literature. Cambridge: CUP.

Pollock Frederick \& Maitland Frederick William. 1898. The history of English law. Cambridge: CUP. Pope, M. 1934. From Latin to modern French. Manchester: Manchester University Press.

Price, G. 1984. Anglo-Norman. In G. Price (ed.), The languages of Britain. London: Edward Arnold.

Rothwell, W. 1975. The role of French in thirteenth-century England. In 58 Bulletin, John Rylands Library, 445-466.

Rothwell, W. 1991. The missing link in English etymology: Anglo-Norman. Medium AEvum LX. 173-196.

Rothwell, W. 1993a. Language and government in medieval England. In 93 Zeitschrift für französische Sprache und Literatur, 258-270.

Rothwell, W. 1993b. From Latin to Anglo-French and middle English: The role of the multilingual gloss. Modern Language Review 88. 582-599.

Rothwell, W. 1996. Adding Insult to injury: The English who curse in borrowed French. In H.-F. Nielsen \& L. Schosler (eds.), The origins and development of emigrant languages. Odense: Odense University Press.

Rothwell, W. 1998. Arrivals and departures: The adoption of French terminology into Middle English. English Studies 79. 144-165.

Rothwell, W. 2001. English and French in England after 1362. English Studies 82. 539-559.

Selden, J. 1683. The Reverse or Back-Face of the English Janus. in Tracts Written by John Selden 54 (Westcottransl.).

Shelly, P. 1921. English and French in England: 1066-1100. Philadelphia: University of Pennsylvania.

Stoljar, S. 1954. A common lawyer's French. Law Library Journal 47. 119-224.

Stubbs, W. 1913. Select charters and other illustrations of English constitutional history. Oxford: The Clarendon Press, 82-83.

Style, W. 1658. Narrationes modernae, or, Modern reports. Introduction. London: Lee, Pakeman, Bedel and Adams.

Suggett, H. 1968. The use of French in England in the Late Middle Ages. In R. Southern (ed.), Essays in medieval history: Selected from the transactions of the royal historical society on the occasion of its centenary, 213-252. London: Macmillan.

Tiersma, P. 1999. Legal language. Chicago: University of Chicago Press.

Trotter, D. 2003. Not as eccentric as it looks: Anglo-French and French French. Forum for Modern Language Studies 39. 427-428.

Vising, J. 1923. Anglo-Norman language \& literature. London: OUP.

Warr, J. 1810. The Corruption and Deficiency of the Laws of England. Soberly Discovered: Or, Liberty Working up to Its Just Height. reprinted in 6 The Harleian Miscellany: 212-225.

Wilson, R. 1943. English and French in England 1100-1300. History 28. 37-60.

Wogan-Browne, J. 2009. Introduction. In J. Wogan-Browne (ed.), Language and culture in medieval Britain, 1-13. York: York Medieval Press.

Woodbine, G. 1943. The language of English law. Speculum 18. 395. 